\title{
Studi Fenomenologi Penyelarasan Makna dan Pengalaman Penikmat Warung Kopi di Ambon
}

\author{
Wulan Purnama Sari \\ Fakultas Ilmu Komunikasi Universitas Tarumanagara \\ Jl. Letjen S Parman No 1, Jakarta Barat 11440 \\ wulanp@ fikom.untar.ac.id
}

Masuk tanggal : 27-02-2020, revisi tanggal : 22-04-2020, diterima untuk diterbitkan tanggal :02-05-2020

\begin{abstract}
Indonesia is one of the largest coffee producing countries in the world. Coffee plants themselves are not native to Indonesia, coffee was brought in by the Dutch during colonial times, since then coffee has become part of the culture and habits of the Indonesian people. Lately the trend of drinking coffee has begun to return to popularity. This can be seen from the large number of coffee shops that have emerged. The trend of drinking coffee and coffee shops also reaches Ambon. Coffee shops in Ambon are also a symbol of peace, that in coffee shops all groups are free to gather. This study examines intercultural communication that occurs in coffee shops in Ambon, and aim to describe how actors involved in communication create their social reality. The study elaborate CMM (Co-Ordinated Management of Meaning) theory and conducted using qualitative methods, with a phenomenological approach. The research data was obtained through in-depth interviews with speakers and also observation and literature review. The results of the study show that the consequences of the conflict in the coffee shop are distinguished by region, Islam and Christianity, so that visitors also become separated between groups. Communication occurs between actors in one group, both between owners and visitors who are in the same category. Different of communication can be seen verbally and non-verbally.
\end{abstract}

Keywords: Ambon, intercultural communication, non-verbal \& verbal communication

\begin{abstract}
Abstrak
Indonesia merupakan salah satu negara produsen kopi terbesar di dunia. Tanaman kopi sendiri bukan tanaman asli Indonesia, kopi dibawa masuk oleh Belanda pada masa penjajahan, mulai sejak itu meminum kopi telah menjadi bagian dari budaya dan kebiasaan masyarakat Indonesia. Belakangan ini trend minum kopi mulai kembali popular. Hal ini dapat dilihat dari banyak jumlah warung kopi yang muncul. Trend minum kopi dan warung kopi ini juga sampai ke Ambon. Warung kopi di Ambon juga merupakan simbol dari perdamaian, bahwa dalam warung kopi semua kelompok bebas berkumpul. Penelitian ini mengkaji komunikasi antar budaya yang terjadi dalam warung kopi di Ambon, serta bertujuan untuk mendeskripsikan bagaimana aktor yang terlibat komunikasi menciptakan realitas sosialnya. Penelitian mengelaborasi teori CMM (Co-Ordinated Management of Meaning) dan menggunakan metode kualitatif, dengan pendekatan fenomenologi. Data penelitian diperoleh melalui wawancara mendalam dengan narasumber dan juga observasi serta kajian pustaka. Hasil dari penelitian menunjukkan akibat dari konflik warung kopi dibedakan berdasarkan wilayahnya, Islam dan Kristen, sehingga pengunjung juga menjadi terpisah antar kelompok. Komunikasi terjadi antar aktor dalam satu kelompok, baik antara
\end{abstract}


pemilik dengan pengunjung yang sama-sama dalam kategori satu kelompok. Perbedaan komunikasi dapat terlihat secara verbal dan non-verbal.

Kata Kunci: Ambon, komunikasi antar budaya, komunikasi non-verbal \& verbal

\section{Pendahuluan}

Indonesia merupakan salah satu negara penghasil kopi terbesar di Indonesia. Berdasarkan data dari International Coffee Organizatation pada tahun 2-17-2018 Indonesia menduduki posisi ke-empat sebagai negara prodosen kopi terbesar di dunia. Peringkat pertama diduduki oleh Brazil, kedua oleh Vietnam, ketiga oleh Kolombia, bahkan selisih Indonesia dengan Kolombia hanya berbeda sebanyak 10juta produksi karung kopi. ("Indonesia salah satu penghasil kopi terbesar, tapi bukan peminum kopi terbanyak - BBC News Indonesia,” 2018)

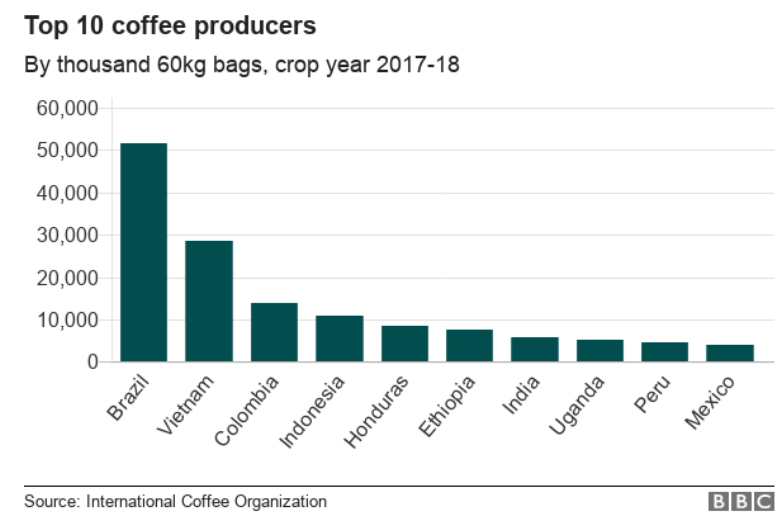

Gambar 1: Negara Produsen Kopi Terbesar di Dunia

Tanaman kopi sendiri bukan merupakan tanaman asli asal Indonesia. Kopi dibawa oleh VOC saat masa penjajahan Belanda sekitar akhir abad ke 16, yang pada waktu ini memiliki niat untuk meruntuhkan monopoli Arab atas perdagangan kopi dunia. Hal inilah kemudian yang mendorong munculnya perkebunan-perkebunan kopi di Indonesia, yang juga pada akhirnya mendorong perkembangan infrastrukstur dan ekonomi di Indonesia. (Gumulya \& Helmi, 2017)

Masukknya tanaman kopi ke Indonesia ini, kemudian mendorong munculnya budaya minum kopi di masyarakat Indonesia. Budaya minum kopi merupakan adopsi dari kebiasaan bangsa luar, yang mulai masuk ke Indonesia sejak jaman penjajahan Belanda. Aprilia (2017) menuliskan dalam artikelnya bahwa kopi memiliki sisi klenik, dimana seringkali kopi dipakai untuk mengisi wadah sajen, serta menjadi bagian dari tradisi zaman kuno masyarakat Indonesia. Kopi dijadikan sebagai pengganti minuman tuak yang dahulu biasa digunakan sebagai persembahan bagi para roh leluhur.

Sejak lima tahun terakhir ini, budaya minum kopi kembali menjadi trend di kalangan masyarakat Indonesia. Istilah "ngopi" bahkan sudah menjadi bagian dari gaya hidup masyarakat Indonesia. Budaya minum kopi sekarang erat dikaitkan dengan kegiatan berkumpul bersama untuk bersosialisasi yang dilakukan di warung atau kedai kopi. Peningkatan trend mengonsumsi minuman berkafein ini bisa 
dilihat sejak tahun 2014. Beberapa laporan dunia juga menunjukkan adanya peralihan dari bar ke kedai kopi. Trend tersebut juga terjadi di Indonesia. Menikmati kopi dianggap sebagai bagian mencintai produk lokal lantaran biji kopi yang melimpah ruah di Indonesia. (Dewi, 2017)

Trend kopi ini juga menyebar tidak hanya di kota-kota besar seperti, Jakarta tetapi juga sampai ke Ambon. Hadirnya kedai kopi di Ambon ini tidak hanya mengikuti trend minum kopi yang memang sedang marak di Indonesia, tetapi juga telah menjadi budaya yang mengakar kuat di Indonesia, tidak terkecuali di Ambon ("Menikmati Kelezatan Kopi Khas Ambon," 2012). Jalan Said Perintah yang terletak di tengah kota Ambon penuh dengan deretan kedai kopi. Lokasi ini hanya berjarak sekitar 15 menit dari pusat Kota Ambon, Lapangan Merdeka, dan juga Monumen Gang Perdamaian (Adiakurnia, 2017). Terdapat beberapa kedai kopi yang sudah terkenal di Ambon, seperti Rumah Kopi Joas, Kafe Sibu-sibu, Toko Kopi Ambon, dan yang lainnya.

Kehadiran kedai kopi di Ambon ini juga merupakan perwujudan perdamaian di Ambon yang pernah dilanda konflik pada tahun 1999. Putra (2018) menjelaskan Kafe Sibu-sibu mulai didirikan pada tahun 2006 sebagai bentuk perdamaian, untuk mengembalikan kesan bahwa warga Maluku juga dapat berbudaya damai dan berkumpul dengan damai.

Kehadiran kedai kopi atau warung kopi di Ambon paska konflik ini menjadikan warung kopi yang berada disana memiliki keunikkan dibandingkan dengan daerah lainnya. Warung kopi di Kota Ambon juga dijadikan sarana tempat rekonsiliasi konflik, tempat bertemu antara pihak yang saling bertikai dan memulai kembali komunikasi diantara dua kelompok. Hal ini menjadikan kedai kopi menjadi ruang publik yang didalamnya terjadi komunikasi.

Kondisi ini menjadikan warung kopi di Ambon juga menjadi salah satu objek tujuan wisata, yang menarik untuk dikunjungi. Wisatawan yang hadir tidak hanya dapat merasakan sensasi kopi Rarobang, kopi khas Ambon, tetapi juga dapat menikmati musik khas Ambon (Fajriyah, 2017). Kondisi yang unik ini menjadikan warung kopi sebagai ruang publik juga menjadi ruang komunikasi antar budaya yang melibatkan dua kelompok yang pernah bertikai dan juga pihak luar seperti para wisatawan, baik asing mau lokal.

Atas dasar ini, peneliti kemudian bermaksud melakukan sebuah penelitian untuk mengkaji mengenai komunikasi antar budaya yang terjadi dalam warung kopi di Ambon antara pemilik warung kopi dengan pengunjung yang bisa saja warga pendatang bahkan wisatawan asing. Komunikasi antar budaya sendiri secara sederhana dapat diartikan sebagai komunikasi yang terjadi antar dua kelompok berbeda budaya. (Samovar, Porter, \& McDaniel, 2010)

Berikut peneliti akan menguraikan beberapa kajian terdahulu yang telah dilakukan untuk memberikan penjelasan mengenai keunikkan dari penelitian ini. Penelitian yang dilakukan di Ambon seringkali dikaitkan dnegan tema penelitian tentang konflik yang pernah terjadi disana. Salah satunya dilakukan oleh Hitiyahubessy, Utami and Widiyatmadi (2015) dengan judul "Resiliensi Perempuan Korban Konflik Ambon”. Penelitian ini berada dalam lingkup ilmu psikologi yang difokuskan pada resiliensi perempuan korban konflik Ambon dan bertujuan untuk mempelajari dinamika psikologis resiliensi perempuan yang 
menjadi korban konflik Ambon. Hasil penelitian ini menunjukan bahwa para perempuan korban konflik Ambon, memiliki kemampuan penyesuaian multidimensi dalam menghadapi berbagai tekanan akibat konflik yang terjadi.

Penelitian berikutnya dilakukan oleh Dandirwalu (2014) dengan tema "Totem Ambon Manise: Membongkar Segregasi Teritorial Berbasis Agama di Kota Ambon”. Penelitian ini menggunakan teori totem dari Durkheim untuk menjelaskan realita segregasi yang terjadi di Ambon paska konflik. Adanya konflik menyebabkan munculnya segregasi wilayah antara kelompok agama Islam dan Kristen di Ambon. Hal ini terjadi dengan alasan keamanan, kenyamanan antar kelompok, serta masih adanya trauma akibat konflik tersebut.

Penelitian berikutnya dilakukan oleh Hakis (2015) dengan judul "Komunikasi Antar Umat Beragama di Kota Ambon". Penelitian ini mengkaji peranan dari komunikasi dalam menciptakan kerukunan antar kelompok agama di Ambon. Hasil dari penelitian menunjukkan terdapat beberapa hal yang harus diperhatikan dalam komunikasi untuk menciptakan kerukunan, salah satunya adalah penggunaan bahasa untuk menghindari hasutan dan peranan dari ruang publik sebagai tempat perjumpaan level sosio kultural.

Penelitian berikutnya mengambil tema tentang warung kopi yang dilakukan oleh Santoso (2017) dengan judul "Etnografi Warung Kopi: Politik Identitas Cangkrukan di Kota Surabaya dan Sidoarjo". Penelitian ini mengkaji budaya cangkrukan yang terjadi di warung kopi. Kemudian Erman (2014) melakukan penelitian dengan judul "Dinamika Komunitas Warung Kopi Dan Politik Resistensi Di Pulau Belitung”. Kedua penelitian tersebut mengambil tempat di warung kopi yang kemudian dikaitkan dnegan lingkup budaya serta politik.

Berdasarkan kajian terdahulu yang telah dijelaskan diatas dapat dilihat bahwa penelitian ini memiliki keunikkan, dalam artian penelitian ini dilakukan di Ambon tapi tidak mengkhususkan diri dalam tema konflik maupun kerukunan, tetapi mengangkat tema trend minum kopi yang terjadi di Indonesia sehingga tempat penelitian difokuskan dalam warung kopi. Warung kopi yang merupakan ruang publik ini seringkali dikaitkan dengan komunikasi politik yang terjadi didalamnya, tetapi pada penelitian ini mengkhususkan pada komunikasi antar budaya yang terjadi didalam warung kopi dan bagaimana aktor yang terlibat dalam komunikasi tersebut membentuk realitas sosialnya. penelitian ini bertujuan untuk mengetahui bagaimana komunikasi antar budaya yang terjadi antara pemilik dengan pengunjung warung kopi di Ambon; dan untuk mengetahui bagaimana komunikator yang terlibat membentuk realitas sosialnya.

Penelitian ini menggunakan konsep komunikasi verbal, non verbal serta teori CMM (Co-Ordinated Management of Meaning). Komunikasi verbal adalah penyampaian dan penerimaan pesan dengan menggunakan bahasa lisan dan tulisan (Cangara, 2008). Sementara, Samovar, Porter \& McDaniel (2010) menjelaskan komunikasi non-verbal meliputi semua stimulus non-verbal dalam sebuah situasi komunikasi yang dihasilkan, baik oleh sumbernya maupun penggunanya dalam lingkungan dan yang memiliki nilai pesan yang potensial untuk menjadi sumber atau penerima. 
Kemudian West and Turner (2008) menuliskan terdapat beberapa asumsi utama dalam teori CMM ini. Pertama, manusia hidup dalam komunikasi, asumsi ini mendasarkan bahwa kehidupan utama manusia atau realitas sosial manusia dibentuk melalui komunikasi sebagai dasarnya. Asumsi kedua mengatakan manusia saling menciptakan realitas sosial, dasar dari asumsi ini adalah adanya percakapan, karena realitas sosial antar manusia dibentuk melalui percakapan. Asumsi ketiga menyebutkan transaksi informasi bergantung kepada makna pribadi dan interpersonal, makna pribadi adalah makna unik yang dimiliki seseorang sedangkan makna interpersonal adalah hasil yang muncul ketika dua orang sepakat akan interpretasi mengenai sebuah interaksi.

Menurut para teoritikus CMM, manusia mengorganisasikan makna dengan cara yang hierarkis. Hieararkis makna ini terdiri dari pola budaya, naskah kehidupan, hubungan, episode, tindak tutur, dan isi. Berikut adalah gambar dari hierarki makna.

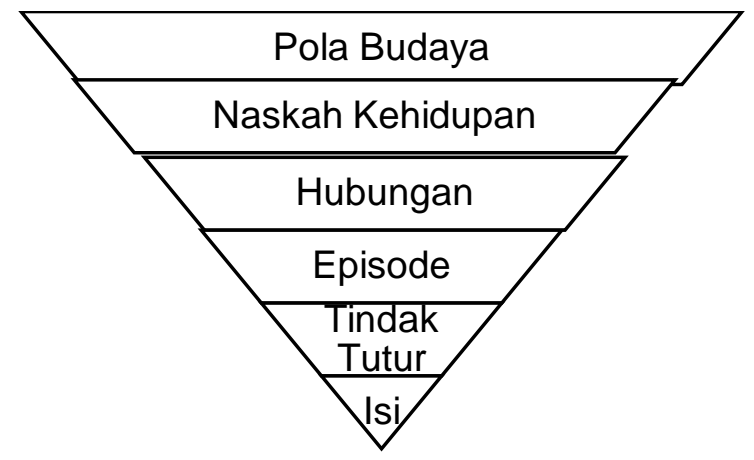

\section{Gambar 2: Hierarki Makna}

Level isi merupakan langkah awal dimana data mentah dikonversikan menjadi makna. Tindak tutur merupakan tindakan yang dilakukan melalui berbicara, misalnya: bertanya, memberikan pujian, atau mengancam. Episode merupakan rutinitas komunikasi yang memiliki awal, pertengahan, dan akhir yang jelas. Episode mendeskripsikan konteks dimana orang bertindak. Level berikutnya adalah hubungan yang merupakan kesepakatan dan pengertian antara dari dua orang. Level naskah kehidupan merupakan kelompok-kelompok episode masa lalu atau masa kini yang menciptakan suatu sistem makna yang dapat dikelola bersama dengan orang lain. Level terakhir pola budaya yang merupakan gambaran mengenai dunia dan bagaimana hubungan seseorang dengan hal tersebut. West \& Turner (2008)

\section{Metode Penelitian}

Penelitian ini dilakukan dengan menggunakan metode penelitian kualitatif, khususnya dengan menggunakan pendekatan fenomenologi. Patton (2002) menjelaskan metode fenomenologi berusaha mencari sifat dasar dari suatu fenomena, mencari apa yang menyebabkan fenomena itu terjadi. Metode ini berfokus tentang eksplorasi bagaimana manusia menciptakan pengalaman dan 
mengubah pengalaman tersebut menjadi kesadaran, baik sebagai makna individual maupun makna yang dibagi bersama. Fenomena yang akan dikaji dalam penelitian adalah hadirnya trend warung kopi yang juga melanda Ambon, hanya saja perbedaannya warung kopi di Ambon ini juga menjadi sebuah simbol perdamaian. Penelitian ini berfokus untuk mengkaji komunikasi antar budaya yang terjadi dalam warung kopi di Ambon, komunikasi antara pemilik warung kopi dengan pengunjungnya, serta bagaimana para aktor atau komunikator yang terlibat tersebut membentuk realitas sosialnya dalam warung kopi.

Subjek penelitian ini adalah komunikasi antar budaya yang terjadi dalam warung kopi di Ambon, serta bagaimana para komunikator yang terlibat menciptakan realitas sosial yang mereka miliki dalam perbedaan budaya. Sedangkan objek penelitian ini adalah pemilik warung kopi di Ambon, yaitu warung kopi Sibu-Sibu dan warung kopi Joas beserta dengan pelanggannya. Bagian ini akan dijelaskan lebih lanjut dalam bagian narasumber.

Narasumber dalam penelitian adalah pemilik, pekerja di warung kopi, serta juga pengunjung di warung kopi. Kemudian ditambah beberapa pakar mengenai perdamaian di Ambon. Teknik pemilihan narasumber menggunakan cara snowball sampling, dimana peneliti mendapatkan masukan mengenai narasumber yang sesuai untuk penelitian ini.

Narasumber pertama adalah Bapak Jacky Manuputty yang merupakan tohoh Kristen yang aktif dalam proses rekonsiliasi konflik. Bapak Abidin Wakano yang merupakan tokoh penggagas perdamaian dari pihak Islam. Ibu Hilda Lorobesi yang merupakan aktivis perdamaian dan perempuan. Bapak Benny sebagai salah satu warga Kota Ambon.

Teknik pengumpulan data dilakukan dalam penelitian ini adalah dengan cara wawancara mendalam kepada narasumber dan juga observasi. Sugiyono (2013) menuliskan wawancara adalah proses memperoleh keterangan untuk rujukan penelitian dengan cara tanya jawab. Sedangkan observasi sebagai metode atau cara mengadakan pencatatan secara sistematis mengenai tingkah laku dengan melihat atau mengamati individu atau kelompok secara langsung.

Pada penelitian ini data yang telah diperoleh melalui wawancara dan obersevasi, kemudian diolah dan dianalisis sehingga dapat digambarkan temuan dari penelitian dan juga dikaji kembali dengan bantuan studi pustaka yang telah lebih dahulu dilakukan oleh peneliti.

\section{Hasil Penemuan Dan Diskusi}

Konflik di Ambon terjadi mulai dari tahun 1999 dan kemudian pecah kembali pada tahun 2001 (Aziz, 2011). Konflik ini melibatkan dua kelompok agama, yaitu Islam dan Kristen. Konflik tersebut diperkirakan menelan korban 434 orang (Rahawarin, 2013). Secara historis kedua kelompok ini hidup rukun sebelum terjadinya konflik, Ambon dikenal sebagai "Ambon Manise" yang toleran terhadap agama dan relasi kemanusian (Qurtuby, 2017). Sangat umum terjadi perkawinan campur diantara kedua kelompok kepercayaan tersebut, bahkan dikenal kearifan lokal yang mengakar pada masyarakat yang bernama pela gandong mengandung arti hubungan kekerabatan meski berbeda agama. Dapat pula diartikan hidup 
berdampingan dengan penuh tenggang rasa dalam perbedaan agama, tetapi tidak saling mempengaruhi untuk masuk dan memeluk suatu agama tertentu (Bakri, 2015).

Hal ini hilang ketika meletusnya konflik pada tahun 1999, yang menelan banyak korban tidak hanya dalam hal korban jiwa tapi juga kerugian material. Upaya perdamaian dilakukan pada tahun 2001 dengan mempertemukan kedua pihak yang bertikai di Sulawesi Selatan dan menghasilkan perjanjian Mallino II (Krisandi, Setyono, \& Utomo, 2013). Adanya perjanjian damai tersebut mendorong masyarakat juga untuk ikut serta dalam mewujudkan perdamaian, salah satunya adalah melalui rumah kopi atau kedai kopi. Rumah kopi merupakan salah satu ruang publik yang memiliki peran penting di Ambon. Di rumah kopi tersebut warga Ambon yang berasal dari komunitas Islam dan Kristen serta berbagai etnis dan status sosial bisa bertemu, dari sekedar hang out bersama teman-teman kantor, melakukan pembicaraan bisnis bahkan lobi-lobi politik di antara politisi lokal. Pada kasus Ambon ini, kedai kopi merupakan ruang publik atau public sphere yang berfungsi sebagai tempat rekonsiliasi (Ernas, 2016).

\section{Ruang Publik dan Komunikasi di Ambon Paska Konflik}

Konflik yang terjadi di Ambon tidak hanya menimbulkan korban jiwa, dan membawa kerugiaan secara material tetapi juga membawa permasalahan bahkan setelah konflik selesai. Dandirwalu (2014) dalam penelitiannya menyebutkan bahwa konflik yang terjadi di Ambon menimbulkan adanya segregasi wilayah antara Islam dan Kristen. Kedua kelompok yang awalnya hidup berdampingan dalam satu wilayah sebelum konflik, menjadi terpisah dan menjadi satu dengan kelompoknya masing-masing. Sebagai contoh adalah wilayah Batu Merah di Kota Ambon yang sebelum konflik menjadi domisili bagi kedua kelompok, sekarang menjadi wilayah domisili bagi kelompok Islam.

Segregasi wilayah ini juga berakibat pada adanya segregasi ruang publik antar kelompok, dimana dalam hal ini adalah warung kopi. Ruang publik, seperti warung kopi juga menjadi terbagi antar wilayah dan antar kelompok, dimana orang dari masing-maisng kelompok akan pergi ke warung kopi yang berada di wilayah kelompoknya masing-masing. Kemudian juga terdapat kecenderungan bahwa masing-masing kelompok memiliki kekhawatiran dan keengganan untuk pergi ke warung kopi di wilayah yang bukan milik kelompoknya. Hal ini penulis ketahui berdasarkan hasil wawancara dengan narasumber.

Salah satu narasumber, Bapak Benny menjelaskan bahwa tidak ada larangan secara resmi untuk pergi atau berkunjung ke daerah yang bukan merupakan kelompoknya, namun ada semacam norma di dalam masyarakat bahwa untuk berkunjung ke daerah kelompok lain sebaiknya dilakukan saat siang hari, dan dilakukan bila memiliki undangan dari kenalan yang berasal dari kelompok lain. Oleh karenanya, pengunjung warung kopi kebanyakan terbagi ke dalam kelompokkelompok, tidak umum bagi kelompok Islam untuk pergi ke warung kopi di wilayah Kristen demikian juga sebaliknya.

Kemudian, selain terdapat perbedaan segregasi antar wilayah, juga terdapat perbedaan dalam tampilan fisik warung kopi. Warung kopi di wilayah Islam, cenderung bernuansa modern, sedangkan warung kopi di wilayah Kristen lebih 
bernuansa tradisonal. Hal ini dapat dilihat mulai dari nama warung kopi, desain interior, dan juga musik yang diputar. Sebagai contoh salah satu warung kopi di wilayah Kristen bernama Kafe Sibu-Sibu, kafe tersebut bernuansa tradisional dimulai dari interior, dimana dindingnya dipenuhi gambar artis atau atlet keturunan Maluku, kemudian lagu yang diputar adalah lagu tradisional Maluku, makanan yang disajikan juga makanan tradisional khas Maluku.

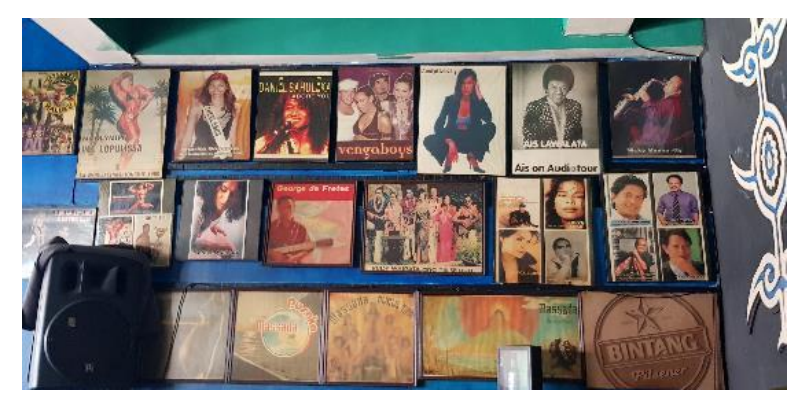

Gambar 3: Suasana Interior Kafe Sibu-Sibu

Hal tersebut sangat berbeda dengan warung kopi di wilayah Islam yang sangat bernuansa modern. Salah satu warung kopi di wilayah Islam yang cukup terkenal adalah Kafe Pelangi, warung kopi termasuk yang paling ramai dikunjungi. Seperti dapat dilihat pada gambar 4 di bawah ini, interior kafe tersebut sangat modern dan berbeda dengan Kafe Sibu-Sibu, musik yang diputarpun merupakan music-musik modern, menu makananpun lebih variatif dibandingkan dengan Kafe Sibu-Sibu, Kafe Pelangi menyediakan menu makanan barat dan juga tradisional sekaligus. Kafe juga dilengkapi dengan pendingin ruangan.

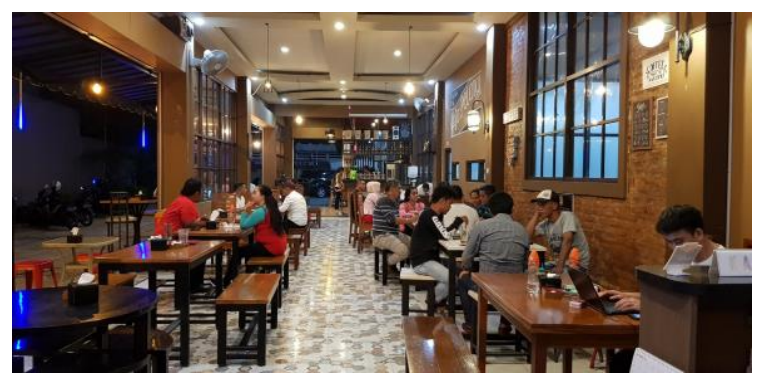

Gambar 4: Suasana Kafe Pelangi

Walaupun terjadi segregasi wilayah dan ruang publik akibat dari konflik di Ambon, tetapi tidak mengurangi peran dari ruang publik, seperti warung kopi dalam menjadi pesan perantara damai. Selama masa konflik, warung kopi kerap dijadikan tempat berkumpul antar kedua kelompok dan berdiskusi mengenai jalur yang aman, kondisi di lingkungan masing-masing, dan juga tempat untuk memulai rekonsiliasi paska konflik. Hal ini juga ditegaskan oleh salah satu narasumber Bapak Jacky Manuputty, yang menjelaskan tentang pemanfaatan ruang publik paska konflik yang dijadikan tempat rekonsiliasi dengan bantuan anak-anak muda, dengan mengadakan beragam acara dengan tema perdamaian, mulai dari acara music, lukisan, puisi, dll. Pemanfaatan ruang publik sebagai tempat rekonsiliasi terutama 
Wulan Purnama Sari: Studi Fenomenologi Penyelarasan Makna dan Pengalaman Penikmat Warung Kopi di Ambon

terjadi di warung kopi yang terletak di perbatasan wilayah, seperti Warung Kopi Sibu-Sibu.

Dalam ruang publik inilah terjadi interaksi antar kelompok yang dahulu pernah bertikai. Interaksi ini juga menjadi berkembang tidak hanya antar kelompok warga Ambon yang pernah bertikai, tetapi juga dengan wisatawan yang datang ke Ambon. Paska konflik, Ambon menjadi lebih terbuka dan wisatawan, baik lokal maupun mancanegara mulai berdatangan ke Ambon. Terlebih lagi banyak warga migran Ambon yang berada di Belanda datang berkunjung ke Ambon. (Maradona, 2011)

Warung kopi menjadi salah satu tempat yang sering direkomendasikan jika datang berkunjung ke Kota Ambon, salah satunya adalah warung kopi Sibu-Sibu (Putra, 2018). Berdasarkan hasil observasi dan wawancara dengan pekerja disana, warung kopi umumnya ramai dikunjungi wisatawan lokal pada siang hari dan wisatawan asing pada malam hari. Pemilik dan pekerja warung kopi sudah terbiasa melayani dan berinteraksi dengan orang dari luar Ambon, sebagai warga asli mereka sangat ramah dalam melayani dan juga terbuka terkait masalah konflik yang pernah mereka hadapi dulu.

Keterbukaan warga Ambon juga didasari pada budaya yang mereka miliki. Anggoro, Finesso and Wresti (2013) menuliskan masyarakat Ambon sudah terbiasa memiliki budaya bernyanyi dan menari, dan di ruang publik seperti warung kopi kebudayaan tersebut juga mereka tunjukkan. Musik juga dijadikan sarana rekonsiliasi paska konflik, seperti yang dijelaskan oleh narasumber Bapak Jacky Manuputty. Budaya menyanyi dan menari ini juga memiliki fungsi sebagai perekat sosial, yang menjadikan orang Ambon terbuka kepada pendatang dari luar.

Walaupun, tidak bisa dipungkiri bahwa konflik masih tampak berbekas dalam komunikasi dan interaksi di Ambon, termasuk di dalam warung kopi. Sebagai contoh, narasumber Bapak Benny menjelaskan bahwa panggilan "bung" dikhususkan untuk kakak laki-laki dari kalangan Kristen, sedangkan panggilan "abang" dikhususkan untuk kakak laki-laki dari kalangan Islam. Hal ini menunjukkan segregasi dalam komunikasi verbal yang terjadi di Ambon, walaupun panggilan ini tidak berlaku bagi wisatawan asing, hal ini hanya berlaku bagi sesama warga lokal.

Samovar, Porter \& McDaniel (2010) menjelaskan bahwa komunikasi verbal dapat dilihat dalam bentuk kata-kata, baik secara langsung dan juga tidak langsung. Sedangkan komunikasi nonverbal dan verbal, dapat dilihat dari tampilan dan juga perilaku. Oleh karenanya komunikasi verbal yang terjadi di warung kopi dapat dilihat melalui bentuk panggilan, perbedaan panggilan atau ucapan ini hanya berlaku bagi masyarakat lokal untuk wisatawan tidak ada perbedaan. Komunikasi nonverbal dapat dilihat dari perilaku orang Ambon yang ramah dan terbuka kepada orang dari luar, sebagian akibat dari budaya yang dimiliki orang Ambon.

Komunikasi verbal dan non verbal ini juga terwujud dalam komunikasi yang terjadi antara pengunjung (wisatawan) dengan pemilik dan pekerja di warung kopi (warga lokal). Perbedaan budaya antara wisatawan dengan warga lokal tidak menjadi penghalang komunikasi antar kedua pihak. Komunikasi dan interaksi yang terjadi antar kedua pihak menciptakan makna, dimana dalam konsep CMM makna diorganisasikan secara hierarkis menjadi 6 tahap (West \& Turner, 2008). 
Tahap paling bawah dimulai dari isi, yang merupakan langkah awal dimana data awal baru mulai diubah menjadi makna. Tahap berikutnya, tindak tutur, yang artinya tindakan atau perilaku yang dilakukan dengan berbicara. Pada tahap tindak tutur, komunikator memulai pembicaraan. Setelah itu, naik pada tahap episode dimana perilaku berbicara atau komunikasi menjadi sesuatu yang rutin. Selanjutnya naik ke tahap hubungan, dimana aktor menjalin kesepakatan. Episode dan hubungan menjadi kumpulan dan kemudian naik ke tahap naskah kehidupan. Terakhir, pola budaya gambaran mengenai dunia dan bagaimana hubungan seseorang dengan hal tersebut.

Pada penelitian ini, tahap penciptaan makna hanya sampai pada tahap tindak tutur. Karena komunikator yang diteliti dalam penelitian ini, wisatawan dan pekerja di warung kopi hanya bertemu dan berinteraksi dalam batas waktu tertentu, sehingga untuk naik sampai kegiatan komunikasi menjadi rutinitas menjadi sulit. Komunikasi terjadi dan proses penciptaan makna untuk membentuk realitas dunia komunikator telah terjadi, namun tidak sampai pada tahap terciptanya pola budaya.

\section{Simpulan}

Berdasarkan penjelasan diatas, maka hasil penelitian ini dapat disimpulkan ke dalam beberapa poin utama. Pertama, adanya segregasi wilayah akibat konflik, segregasi juga menyebabkan adanya pemisahan ruang publik antar dua kelompok yang dalam hal ini adalah warung kopi. Komunikasi yang terjadi dalam warung kopi di Ambon melibatkan banyak pihak komunikator, mulai masyarakat Ambon sampai wisatawan asing. Warga lokal ini mulai dari pemilik warung kopi, pekerja di warung kopi, dan juga pengunjung. Sedangkan wisatawan ada asing dan juga lokal yang menjadi pengunjung warung kopi. Komunikasi terjadi antar budaya antara warga lokal dengan wisatawan. Terjadi perbedaan dalam penggunaan simbol komunikasi verbal, namun hanya untuk sesama warga lokal. Sedangkan untuk non verbal tidak ada perbedaan, walaupun masih terdapat jarak antar kelompok yang pernah bertikai.

Kedua, dikarenakan faktor waktu komunikasi yang terjadi di warung kopi terbatas hanya pada tahap tindak tutur berdasarkan teori CMM. Karena komunikator yang diteliti dalam penelitian ini, wisatawan dan pekerja di warung kopi hanya bertemu dan berinteraksi dalam batas waktu tertentu, sehingga untuk naik sampai kegiatan komunikasi menjadi rutinitas menjadi sulit.

Berikut dikemukakan saran sebagai bagian dari penelitian ini. Saran ini bersifat akademis yang ditujukan bagi peneliti yang hendak mengambil tema serupa ataupun melakukan pengembangan dari penelitian ini. Pertama, penelitian lanjutan dapat dilakukan dengan metode kuantitatif untuk mengujuk fenomena terpaan media terhadap tingkat frekuensi datangnya pengunjung ke warung kopi di Ambon. Kedua, penelitian lanjutan juga dapat dilakukan dengan meneliti komunikasi yang terjadi antar kelompok yang pernah bertikai di Ambon, bagaimana segregasi membawa dampak dalam kehidupan bermasyarakat, maupun bagaimana pola budaya yang terbentuk paska konflik antar kedua kelompok. 
Wulan Purnama Sari: Studi Fenomenologi Penyelarasan Makna dan Pengalaman Penikmat Warung Kopi di Ambon

\section{Ucapan Terima Kasih}

Penulis mengucapkan terima kasih kepada seluruh narasumber yang telah membantu dan bersedia bekerja sama selama proses penelitian ini berlangsung. Kemudian, ucapan terima kasih juga diberikan kepada Dikti sebagai pemberi dana dan Universitas Tarumanagara.

\section{Daftar Pustaka}

Adiakurnia, M. I. (2017, November 14). Hangatnya Jalan Said, Surganya "Coffee Shop" di Ambon. Travel Kompas.Com. Retrieved from https://travel.kompas.com/read/2017/11/14/140400027/hangatnya-jalansaid-surganya-coffee-shop-di-ambon

Anggoro, A. P., Finesso, G. M., \& Wresti, M. C. (2013, October 22). Ambon (Teruslah) Menyanyi. Travel Kompas.Com. Retrieved from https://travel.kompas.com/read/2013/10/22/0829062/Ambon.Teruslah.Me nyanyi

Aprilia, A. (2017, August 26). Tradisi Minum Kopi di Indonesia Ternyata Muncul Setelah Belanda Membawa Biji Kopi. Lifestyle Okezone.Com. Retrieved from https://lifestyle.okezone.com/read/2017/08/25/406/1763407/okezoneweek-end-tradisi-minum-kopi-di-indonesia-ternyata-muncul-setelahbelanda-membawa-biji-kopi

Aziz, Na. A. (2011, October 2). Pertikaian di Ambon Bukan Konflik Agama. Nasional Kompas.Com. Retrieved from https://nasional.kompas.com/read/2011/10/02/20394476/Pertikaian.di.Am bon.Bukan.Konflik.Agama.

Bakri, H. (2015). Resolusi Konflik Melalui Pendekatan Kearifan Lokal Pela Gandong di Kota Ambon. The POLITICS: Jurnal MAgister Ilmu Politik Universitas Hasanuddin, 1(1), 51-60. Retrieved from https://media.neliti.com/media/publications/102761-ID-resolusi-konflikmelalui-pendekatan-kear.pdf

Cangara, H. (2008). Pengantar Ilmu Komunikasi, Edisi Revisi 2008 PT. Raja Grasindo Persada, Jakarta.

Dandirwalu, R. (2014). Totem Ambon Manise: Membongkar Segregasi Teritorial Berbasis Agama di Kota Ambon. Jurnal Antropologi Indonesia, 35(1), 30 44. Retrieved

from http://journal.ui.ac.id/index.php/jai/article/viewFile/5511/3534

Dewi, T. L. (2017, November 10). Mendarah Daging Jadi Gaya Hidup Orang Indonesia, Ternyata dari Sini Budaya Ngopi Berawal. Travel Tribunnews.Com. Retrieved from https://travel.tribunnews.com/2017/11/10/mendarah-daging-jadi-gayahidup-orang-indonesia-ternyata-dari-sini-budaya-ngopi-berawal

Erman, E. (2014). Dinamika Komunitas Warung Kopi Dan Politik Resistensi Di Pulau Belitung. Masyarakat Indonesia, 40(1), 89-107. Retrieved from http://ejournal.lipi.go.id/index.php/jmiipsk/article/view/108/26 
Ernas, S. (2016). Architecture of Peace in Ambon: Reading Dynamics of Peace After Ten Years of Conflict. Al-Albab, 5(2), 219-236. Retrieved from https://jurnaliainpontianak.or.id/index.php/alalbab/article/view/504/368

Fajriyah, T. (2017). Menjajal Kenikmatan Kopi Khas Ambon, Kopi Rarobang. Retrieved April 22, 2019, from https://www.cnnindonesia.com/gayahidup/20170425122415-262-209927/menjajal-kenikmatan-kopi-khasambon-kopi-rarobang

Gumulya, D., \& Helmi, I. S. (2017). Kajian Budaya Minum Kopi di Indonesia. Dimensi, 13(2), 153-172. Retrieved from https://trijurnal.lemlit.trisakti.ac.id/index.php/dimensi/article/viewFile/178 $5 / 1545$

Hakis, H. (2015). Komunikasi Antar Umat Beragama di Kota Ambon. Jurnal Komunikasi Islam, 5(1), 98-113. https://doi.org/10.15642/JKI.2015.5.1.98113

Hitiyahubessy, A. A., Utami, S., \& Widiyatmadi, E. (2015). Resiliensi Perempuan Korban Konflik Ambon. PREDIKSI, 4(1), 19. Retrieved from http://journal.unika.ac.id/index.php/pre/article/view/499/425

Indonesia salah satu penghasil kopi terbesar, tapi bukan peminum kopi terbanyak BBC News Indonesia. (2018). Retrieved April 22, 2019, from https://www.bbc.com/indonesia/majalah-43772934

Krisandi, E., Setyono, B., \& Utomo, T. C. (2013). Resolusi Konflik Komunal di Maluku Pasca Reformasi. Jurnal Ilmu Pemerintahan, 1-11. Retrieved from https://media.neliti.com/media/publications/111314-ID-resolusi-konflikkomunal-di-maluku-pasca.pdf

Maradona, S. (2011, March 20). 60 Tahun Lika Liku Orang Maluku di Belanda | Republika Online. Republika.Co.Id. Retrieved from https://www.republika.co.id/berita/breakingnews/internasional/11/03/20/170982-60-tahun-lika-liku-orang-maluku-dibelanda

Menikmati Kelezatan Kopi Khas Ambon. (2012). Retrieved April 22, 2019, from https://www.beritasatu.com/kuliner/30928-menikmati-kelezatan-kopikhas-ambon.html

Patton, M. Q. (2002). Qualitative analysis and interpretation. In Qualitative research \& evaluation methods.

Putra, M. A. (2018). Harum Kopi Pembawa Damai di Rumah Kopi Sibu Sibu Ambon. Retrieved April 22, 2019, from https://www.cnnindonesia.com/gaya-hidup/20180113162923-262-

268628/harum-kopi-pembawa-damai-di-rumah-kopi-sibu-sibu-ambon

Qurtuby, S. Al. (2017). Belajar Toleransi Agama dari Ambon. Retrieved April 22, 2019, from https://www.liputan6.com/news/read/3100627/belajartoleransi-agama-dari-ambon

Rahawarin, Y. (2013). Kerjasama Antar Umat Beragama: Studi Rekonsiliasi Konflik Agama di Maluku dan Tual. KALAM, 7(1), 95-120. Retrieved from http://ejournal.radenintan.ac.id/index.php/KALAM/article/view/451/2626

Samovar, L. A., Porter, R. E., \& McDaniel, E. R. (2010). Komunikasi Lintas Budaya (7th ed.). Salemba Humanika. 
Wulan Purnama Sari: Studi Fenomenologi Penyelarasan Makna dan Pengalaman Penikmat Warung Kopi di Ambon

Santoso, L. S. (2017). Etnografi Warung Kopi: Politik Identitas Cangkrukan di Kota Surabaya dan Sidoarjo. Mozaik Humaniora, 17(1), 113-125. https://doi.org/10.20473/MH.V17I1.6594

Sugiyono. (2013). metodologi penelitian kuantitatif kualitatif dan R \& D. In Bandung: Alfabeta. https://doi.org/10.1164/rccm.200409-1267OC

West, R., \& Turner, L. H. (2008). Pengantar Teori Komunikasi Analisis dan Aplikasi. (N. Setyaningsih, Ed.). jakarta: Salemba Humanika. 